\title{
AN EMPIRICAL EXAMINATION OF ACCOUNTING COMPARABILITY: GOODWILL RECOGNITION AND DISCLOSURE IN SELECTED CENTRAL EUROPEAN COUNTRIES
}

\author{
Ewa Wanda Maruszewska ${ }^{1}$ Marzena Strojek-Filus², Jiří Pospíšil ${ }^{3}$ \\ ${ }^{1}$ Department of Business Informatics and International Accounting, Faculty of Finance and Insurance, University \\ of Economics in Katowice, Ul. 1 Maja 50, 40-287 Katowice, Poland \\ ${ }^{2}$ Department of Accounting, Faculty of Finance and Accounting, Faculty of Finance and Insurance, University \\ of Economics in Katowice, Ul. 1 Maja 50, 40-287 Katowice, Poland \\ ${ }^{3}$ Department of Financial Accounting and Auditing, Faculty of Finance and Accounting, University of Economics \\ Prague, nám. W. Churchilla 1938/4, 13067 Praha 3, Czech Republic
}

To link to this article: https://doi.org/10.11118/actaun201967051309

Received: 8. 3. 2019, Accepted: 27. 8. 2019

To cite this article: MARUSZEWSKA EWA WANDA, STROJEK-FILUS MARZENA, POSPÍŠIL JIŘÍ. 2019. An Empirical Examination of Accounting Comparability: Goodwill Recognition and Disclosure in Selected Central European Countries. Acta Universitatis Agriculturae et Silviculturae Mendelianae Brunensis, 67(5): 1309-1323.

\begin{abstract}
Over the last few decades, there have been unusually frequent changes in the required accounting rules and methods for measuring and reporting positive and negative goodwill of business entities and capital groups. We suggest that the lack of consistent accounting regulations among Central Eastern European countries in accounting for positive and negative goodwill distorts the economic content of this very important economic resource and therefore its usefulness for decision making is adversely affected. The aim of this study is to investigate accounting regulations for goodwill in Poland, the Czech Republic, and Slovakia. To achieve this goal, a critical analysis of the literature is conducted, and the applicable legal regulations are analysed. An empirical case study regarding goodwill recognition, measurement, and disclosure is presented based on data received from an actual acquisition transaction. Since the three countries studied are neighbours and cross-country acquisitions are important instruments for regional economic development, we issue a call for regional harmonization of local accounting regulations, preferably based on International Financial Reporting Standards (IFRS).
\end{abstract}

Keywords: accounting comparability, business acquisition accounting, goodwill recognition, negative goodwill

\section{INTRODUCTION}

In today's global economy, goodwill is becoming increasingly important due to the accelerating allocation and concentration of capital manifested in mergers and acquisitions of entities, as well as capital ties in various structures and forms (McNichols and Stubben, 2015). Research conducted in recent years shows that goodwill has an increasingly important position in the assets of capital groups, which are some of the largest economic organizations, particularly in countries with developing capital markets (Uhlenbruck and De Castro, 2000; Ramanna, 2008; Glaum and Wyrwa, 2011; Strojek-Filus, 2013). Moreover, an analysis of international accounting regulations from the last 50 years reveals unusually frequent 
changes to the required rules and methods of measuring and reporting positive and negative goodwill by business entities and capital groups (Copeland and Wojdak, 1969; Francis and Martin, 2010). Such frequent and sweeping changes in the regulations testify to the difficulty and complexity of goodwill, but also to the fact that subsequently introduced regulations have been inadequate or insufficient. Hence, innovative solutions were introduced, often right at the implementation stage, that were criticized by theorists and practitioners (Bugeja and Gallery, 2006; Bini and Bella, 2007; Van Hulzen, 2011).

International Financial Reporting Standards (IFRS) have become guidelines for the changes introduced. However, it is worth noting that many countries, including the countries of Central and Eastern Europe, such as Poland, the Czech Republic, and Slovakia, largely preserved their national accounting laws. The scope and frequency of changes to IFRS has complicated the process of harmonization of accounting rules. As a result, Poland, the Czech Republic, and Slovakia have not kept pace with these changes, or they may fear the effects of changes that are too rapid (Pospiśil and Strojek-Filus, 2017).

Poland, the Czech Republic, and Slovakia are neighbouring post-communist countries located in Central Eastern Europe; they all experienced similar economic transformations following the entire system change that took place at the end of the $20^{\text {th }}$ century. Each country maintained a legal accounting system that constitutes a compilation of previous and new IFRS solutions, former obsolete IFRS standards only, or their old local regulations, despite their incompatibility with existing IFRS (Pospíšil and Vomáčková, 2017; Pospíšil and Vomáčková, 2018). Because there are considerable similarities in overall institutional systems and changes in the accounting laws in these three countries, accounting regulations provide an interesting setting for examining the theoretical background and legislature related to a specific item disclosed in financial reports.

The aim of this study is to investigate the accounting standards for goodwill in Poland, the Czech Republic, and Slovakia in the context of an acquisition transaction, which is the economic phenomena behind this resource. In this study, we pose the hypothesis that the lack of consistent rules for positive and negative goodwill in the accounting rules of these countries distorts the relevance and faithful representation of the financial reports, making it impossible to compare them. Moreover, this state of affairs reveals problems with accounting harmonization and IFRS convergence in the European Union. To achieve the study's goal, we use a critical analysis of the literature and an examination of legal regulations related to goodwill (both positive and negative) in terms of IFRS and the national accounting regulations of Poland, the Czech Republic, and Slovakia. In the empirical analysis, a case study of a business acquisition that involves goodwill recognition, measurement, and disclosure is presented to compare financial reports prepared under IFRS and the national regulations of Poland, the Czech Republic, and Slovakia.

The study contributes to the previous literature in two ways. First, we add to the identification of problems with domestic goodwill accounting regulations. In theory, goodwill is an economic resource that should represent the financial results of a specific economic transaction, a business acquisition, performed by the acquirer. The absence of widely accepted accounting standards negatively influences the relevance of financial accounting information and calls into question faithful representation, which are both important qualitative characteristics of financial reporting. Second, the study presents findings that are important from a regional point of view, as acquisitions of entities from neighbouring countries are important instruments for regional development. In the countries of Central and Eastern Europe, goodwill appeared with the development of the capital markets and the associated possibility of one reporting entity being acquired by another or the acquisition of shares of other entities. The problem described is even more important given the solutions adopted by IFRS for measurement and disclosure of goodwill, as they have been changed several times in the last few years, giving users the impression of the 'permanent instability of these rules' (Strojek-Filus, 2013). Some of these changes were conceptual and fundamental in nature. We suggest that the changes in the IFRS approach to goodwill is one of the reasons for the diverse solutions in Poland, the Czech Republic, and Slovakia. In the process of harmonization and convergence, these countries sought to introduce IFRS into their national solutions with various forms and scope. Our evidence contributes to the debate from the perspective of relevance and suggests that understanding goodwill as an economic resource is a sophisticated problem that requires more attention, particularly at the level of domestic accounting regulations.

This paper is organized as follows. In the following section we develop our hypotheses based on an analytical investigation of international and local accounting regulations for goodwill and on the findings in prior literature. In the third section, we describe the data gathered in the study and present the design of the research, which is built upon the case study. The fourth section depicts the results obtained from the transformation of data, while in the following section we use a theoretical approach to address the research problem. Finally, the last section of the paper concludes. 


\section{Hypotheses Development}

\section{Goodwill as a Reporting Entity's Economic Resource-Prior Literature}

From the point of view of measurement and disclosure in the statement of financial position, goodwill is truly a unique economic resource. According to many authors, goodwill as an asset has an unspecified ability to generate additional benefits for the entity or capital group (Hughes, 1982; Johnson and Tearney, 1993; KamelaSowińska, 1996; Kimbro, 2016). This ability exists only when all the resources of the entity are used in the implementation of specific business processes. Individually used resources, including human factors, are not able to achieve such benefits. From the point of view of accounting theory, goodwill is an asset of the entity. From the standpoint of economic theory, goodwill is additional profit to be achieved by the entity. In his interpretation, Hendriksen (1970) upheld both concepts, formulating goodwill as:

- the value of an asset within intangible assets that was not recognized among the assets of the acquired company,

- the discounted present value of expected future excess earnings above a normal return on capital not including goodwill,

- the excess value of the enterprise other than the sum of the tangible and intangible net assets that have been identified and valued.

Internal goodwill that has not been confirmed by the acquisition of the entity or shares in it is important for valuation purposes but cannot be included in financial reports (Maruszewska and Strojek-Filus, 2016). Thus, accounting rules for acquired goodwill do not relate to this type of goodwill. Internal goodwill is verified only when a real transaction confirms it as purchased goodwill (Bugeja and Gallery, 2006; Bini and Bella, 2007; Strojek-Filus and Maruszewska, 2016).

As financial reports are representations of economic phenomena in words and numbers, the following problems exist in relation to purchased goodwill, which may interfere with the qualitative characteristics of relevance and faithful representation:

- economic fundamentals of the economic resource,

- initial recognition,

- measurement and impairment (amortization) charges in years following the acquisition, and

- disclosure.

The above problems are fundamentally important for investors who invest their capital in various entities, including entities from the countries of Central and Eastern Europe, such as Poland, the Czech Republic, and Slovakia (Uhlenbruck and Castro, 2000). Discrepancies in regulations relating to recognition, measurement, and disclosure of purchased positive and negative goodwill may result in different decisions being made by users of financial reports. Information about goodwill should help users identify the reporting entity's financial strengths and weaknesses, and thus goodwill measurement and disclosure should focus on presenting the effects of an acquisition transaction that changed the entity's economic resources. Moreover, information about goodwill should indicate the extent to which the acquirer has increased its available economic resources, and thus its capacity for generating cash. Given the uncertainty of future cash flows, information about goodwill should help users better predict how future cash flows will be created.

Previous studies referring to goodwill can be divided into four themes. The first deals with goodwill as an enterprise resource, considered from the point of view of economic theory and accounting (Hendriksen, 1970; Miller, 1973; Johnson and Tearney, 1993; McCarthy and Schneider, 1995; Jennings et al., 1996; Hennings et al., 2000). The source of goodwill and its elements have been analysed, and the following components of goodwill have been identified (Henning et al., 2000):

- increase in value of assets,

- value resulting from the creation of holding structures,

- value from synergy,

- value that constitutes a revaluation of an entity's fair value.

The literature emphasizes that goodwill should be separated from 'overpaying' for another entity or its shares, which may have different causes (Cohen, 2005; Churyk, 2005). The importance and economic content of negative goodwill has been stressed (DeMoville and Petrie, 1989; Comiskey et al., 2010); in an efficient market where the interests of both parties to the transaction align, negative goodwill should not exist. A negative value may rather demonstrate overvaluation of the assets of the acquired entity or the shares of the acquired entity. De Moville and Petrie (1989) describe negative goodwill as the manifestation of an error in valuation. They take the view that either goodwill has been created or has not been created, and do not allow for the existence of negative goodwill.

The second group of studies consists of those that relate to the discontinuation of goodwill amortization and the introduction of impairment losses according to SFAS 142. Some studies, inter alia, compared the results of these two solutions (Bugeja and Galery, 2006; Zhang, 2008; Van Hulzen, 2011; Chalmers, et al., 2011). The results of these studies conclude that impairment write-offs are the preferred solution for investors and better reflect the economic value of the entity. However, Van Hulzen's (2011) results indicate some shortcomings of this solution. 
Another group of studies focuses on the issue of disclosure when it comes to combining goodwill with payables and disclosure or non-disclosure of other intangible assets (Glaum and Wyrwa, 2011; Shalev et al., 2013; Carvalho et al., 2016). These studies strongly correspond to IFRS 3.

The largest group of studies includes those that focus on goodwill and its write-off as an instrument of an earnings management strategy (e.g. Beatty and Weber, 2006; Lycklama à Nijeholt and Grift, 2007; Ramanna, 2008; Ramanna and Watts, 2008; Verriest and Gaeremynck, 2009; Lycklama à Nijeholt, 2010; Abu Ghazaleh et al., 2011; Gu and Baruch, 2011; Lycklama à Nijeholt et al., 2012; Bini and Bella, 2007).

In the course of literature and legal standards investigation, two hypotheses were developed:

1. Discrepancies exist in the recognition, measurement, and disclosure of goodwill between IFRS and the local regulations of Poland, the Czech Republic, and Slovakia, as well as among the three neighbouring countries' codifications.

2. Local accounting for goodwill distorts faithful representation, thus lowering the relevance of the information and making it impossible to compare financial reports of acquirers located in Poland, the Czech Republic, or Slovakia.

Harmonization and comparability of financial reports resulting from the harmony in European Union regulation is crucial to create a common market and develop domestic entities through acquisitions. There is a general lack of research on accounting discrepancies of a specific financial report item, such as describing different approaches to accounting for goodwill based on local accounting regulations. Therefore, there is no literature describing the impact of these differences on the relevance of the information disclosed in the context of comparability and faithful representation. Based on this identified gap in the previous literature, the authors chose three neighbouring countries with similar economic backgrounds and very similar development of capital markets for a research study.

\section{Accounting Regulatory Environment}

In Poland, the legal approaches to goodwill are twofold, depending on the type of business entity and the accounting rules adopted. According to the regulations of the European Parliament, IFRS are effective starting from 1 January 2005 for companies listed on public stock exchanges and banks that prepare consolidated financial reports. The financial reports of companies that issue securities already admitted to trading, are applying for admission to trading, or intend to apply for admission to trading (on one of the regulated markets of the European Economic Area countries) must be prepared in accordance with IFRS. Moreover, entities of a capital group whose parent company is required to prepare consolidated financial reports in accordance with IFRS may also apply IFRS to their individual financial reports. In other cases, entities are required to apply the provisions of the Polish Accounting Act (PAR) and the specific legislation (regulations) to which the Act refers.

The principles adopted for identification and measurement of goodwill in these two sets of legislation are quite different. These differences have a conceptual basis primarily associated with consolidated financial reports. PAR extracts the goodwill obtained in the acquisition of another entity and the value of the company, which is the result of the procedures used to consolidate financial statements. PAR distinguishes the following:

a) goodwill, which is the difference between the purchase price of an entity (or its organized part) and the fair value of the acquired net assets of the entity (or its organized part), if lower than the purchase price:

$G=C-F V \quad$ (if: $C>F V$ ),

where:

G..............goodwill,

C.............purchase price (consideration transferred), $F V$............fair value of the acquired entity's net assets;

b) negative goodwill, which is the difference between the purchase price and the fair value of the acquired entity's net assets, if higher than the purchase price:

$n G=C-F V \quad(i f: C<F V)$,

where:

$n G$............negative goodwill.

Goodwill is presented in the statement of financial position as a component of the main asset category of 'intangible assets'. However, acquired negative goodwill is recognized in the financial reports as a component of 'accruals', a category of the entity's liabilities.

In contrast to IFRS, PAR maintains the amortization of goodwill. According to PAR, goodwill is amortized over its useful life using the straight-line method. If the useful economic life cannot be reliably estimated, the period of amortization may not be longer than 5 years. However, this approach is also mixed in character, because PAR allows writing goodwill down for impairment losses that are apart from normal amortization charges. This action is justified when the on-going amortization charges are too small in relation to the actual change in the value of goodwill. The total of annual amortization charges and any additional impairment loss should be consistent with the level of the decrease in the value of goodwill. Furthermore, PAR, like IFRS, does not allow reversing the impairment. 
In the case of negative goodwill, the accounting is much more complex and consists of a kind of compilation of former and current solutions in IFRS regulations. The negative difference is recognized and accounted for depending on the amount:

- if the value does not exceed the fair value of acquired fixed assets, excluding long-term financial assets listed on regulated markets, the entity shows the corresponding separate amount as an item in the consolidated statement of financial position under 'Negative goodwill of subsidiaries', or in 'Accruals';

- if the amount exceeds this value, it is recognized as income on the date the shares that represent control are acquired.

This part of the negative difference, which is disclosed as a liability, is amortized for a period calculated as the weighted average of the economic useful lives of the acquired depreciable fixed assets.

Czech accounting legal regulations (CAR) describe financial accounting in detail, creating coherent national regulation for financial accounting and financial reporting in the Czech Republic. Nevertheless, CAR lists the criteria that allow (or mandate) a company to follow IFRS (as adopted by the European Union) rather than the national financial reporting regulations. Hence there are two sets of legal regulations for accounting, similar to Poland, but the mandatory and voluntary adoption criteria differ. A company whose securities were admitted to trading on one of the regulated capital markets of the European Union is required to prepare both individual and consolidated financial reports in accordance with IFRS. The criteria for voluntary adoption of IFRS that apply to individual financial statements of entities doing business in the Czech Republic are as follows:

- a company's securities were recently delisted, but the company intends to apply for listing of another security within three years,

- a company is required by its parent company to report under IFRS for the purposes of consolidated financial statements under IFRS,

- a company has become a parent company that (regarding the scope of the capital group) is required or chooses to report consolidated financial results under IFRS.

CAR define three types of 'acquisition difference', a unique solution compared to Polish and international accounting for business combinations. One type is called 'goodwill', the second is called 'valuation difference', and the third is called 'consolidation difference'. The first two items are reported as the result of a legal business combination (e.g. acquisition) while the third one is the result of a procedure done to consolidate the financial reports. All three items represent the difference between the consideration transferred (hereafter $\mathrm{C}$ ) and the value of net assets transferred (hereafter AA). All three items are disclosed in the statement of financial position as part of long-term assets. Because the Czech regulations differentiate between consolidation and non-consolidation goodwill, they seem to be a solution to the problems mentioned earlier. However, an in-depth analysis of the methods used to measure goodwill, valuation differences, and consolidation differences shows that all three items are difficult to compare or, in some cases completely incomparable due to the theoretical discrepancies underlying each item's valuation process.

According to CAR, goodwill is the difference between the value of an acquired business (acquired through regular purchase, acquired as a contribution to equity, or as a result of an acquisition or similar business combination) and the net assets transferred from the acquired company to the acquirer. For the purpose of goodwill recognition, the value of net assets is calculated as the difference between the fair value of the assets (based on an expert's valuation report) and the book value of liabilities assumed:

$G=C-F V \triangle B V$,

where:

$F V \triangle B V$....fair value of entity's acquired assets minus book value of liabilities assumed.

In contrast to IFRS and PAR, CAR provisions do not allow additional separate identification of intangible assets that were not recognized on the acquired company's statement of financial position at the time of the business combination.

Moreover, goodwill calculated under the Czech national legislation may result in both a negative and positive amount; however, in either case, the treatment of goodwill is the same. As a result, goodwill is separately recognized as part of longterm intangible assets as either a positive or negative value. In the years following the business combination, goodwill is amortized on a straightline basis over not exceeding 5 years. Because under CAR goodwill can have a positive or negative value, its amortization is presented among expenses or recognized gains, respectively, in the income statement.

The valuation difference of acquired assets is the difference between the value of the acquired business (acquired through regular purchase, acquired as a contribution to equity, or as a result of an acquisition or similar business combination) and the net assets transferred from the acquired company to the acquirer. The value of the net assets required to measure the valuation difference is calculated as the difference between the book value of assets and liabilities as shown in the following equation:

$V D=C-B V$, 
where:

$V D$............valuation difference of acquired assets,

$B V$............ book value of the acquired entity's assets minus book value of liabilities assumed.

Under CAR, similar to the recognition of goodwill, identification of new intangible assets is not allowed in the process of recognizing a valuation difference. A valuation difference of acquired assets may result in either negative and positive amounts. Both negative and positive valuation differences are separately disclosed in long-term tangible assets in the statement of financial position and are amortized on a straight-line basis over 15 years. When the assets transferred do not include longterm assets with a remaining useful life of more than 15 years, the amortization period may be shortened if properly explained in the notes to the financial report. Moreover, the remaining portion of the valuation difference is required to be expensed on the date the last part of the long-term tangible or intangible assets is disposed of.

To summarize, similar to PAR, users of Czech financial reports need to distinguish between goodwill presented in accordance with IFRS and goodwill recognized in compliance with CAR. Moreover, financial reports under CAR may contain two additional items resulting from the accounting for business combinations: a valuation difference of acquired assets and a consolidation difference. Although all four are types of 'acquisition differences' because they represent a difference between the acquisition price and the value of net assets transferred, significant discrepancies between IFRS and PAR make comparability quite challenging.

The conceptual framework for accounting in Slovakia is also two-fold and like Poland and the Czech Republic, Slovak accounting law specifies which companies are obliged to report under IFRS regulations. The scope of companies subject to IFRS differs from those under PAR and CAR. According to Slovakia's accounting code (SAR), companies fulfilling the following criteria are required to report using IFRS:

- entities exceeding at least two of three listed criteria: assets greater than 170 million EUR, revenues greater than 170 million EUR, or number of employees greater than 2,000;

- banks, insurance companies, and stock exchanges (including branches and subsidiaries).

Voluntary adoption of IFRS is permitted for companies meeting specific criteria:

- current listing of securities on one of the European (regulated) stock markets;

- broker companies and similar institutions (including branches and subsidiaries);

- a company that is a successor of another company that previously reported under IFRS.
IFRS regulations also apply to consolidated financial reports, regardless of the criteria mentioned above. SAR does not regulate the consolidation of financial reports in detail, but instead refers to the IFRS (as accepted by the European Union). In Slovakia, any consolidated financial reports are therefore prepared using IFRS, in contrast to individual financial reports, which are subject to legal dualism.

As a result of the above-mentioned accounting regulations, two types of goodwill are seen in the financial reports of entities doing business in Slovakia: goodwill calculated in accordance with IFRS and SAR goodwill.

According to SAR, goodwill represents the difference between the value of the acquired business (acquired through regular purchase, acquired as a contribution to equity, or as a result of an acquisition or similar business combination) and the net assets transferred from the acquired company to the acquirer:

$G=C-F V$.

The value of net assets is calculated as the difference between assets and liabilities measured at their fair value on the day of the business combination. The resulting goodwill value may be positive or negative and is separately disclosed as a long-term intangible asset in the statement of financial position.

In addition to amortizing the value of goodwill for a period no longer than 20 years, under SAR, the treatment of goodwill in the years following the business combination require the acquirer (or successor) to test goodwill for its potential to influence future gains or losses, also known as impairment. If goodwill is found to be impaired, the successor company is allowed to completely or partially write it off at the time of the determination, directly affecting gains or losses in the income statement. The test for impairment should be done on a yearly basis, in addition to the straight-line amortization for the period.

To summarize, users of financial reports prepared by entities doing business in Slovakia may observe two types of goodwill: that recognized in accordance with IFRS and that calculated under SAR. Slovak accounting for goodwill is similar to PAR but differs from CAR. Similarly, the position of goodwill in Slovak financial reports makes comparisons difficult due to the existing dualism of accounting regulations and the different approaches to accounting for goodwill present in rules of the Czech Republic, its neighbour.

\section{MATERIALS AND METHODS}

In searching for the economic transaction hidden behind goodwill numbers, we examined the scope of possible differences arising from IFRS, PAR, 
CAR, and SAR by testing a real case of a business combination reported in accordance with Polish accounting law. The business combination was accounted for as the acquisition of company $B$ by company A, where company A was identified as the acquirer. The book values and fair values of all identifiable assets and liabilities of company $\mathrm{B}$ were available based on the documentation of the acquisition process that took place between the two Polish limited liability companies. Hence, documentary research was done to collect the data. We gained access to all required information about the purchase price and important details regarding the consideration transferred to the acquired company, as well as documentation from the legal procedures following the acquisition.

An acquisition accounted for in accordance with PAR was chosen for the study primarily because despite Polish accounting's use of book values, Polish accounting for business combinations requires the fair value measurements that are needed for reporting under IFRS. Moreover, the Polish legal procedure is consistent with the standards of the European Union merger directive and requires valuation of the combining entities on the day common draft terms are issued. As the aim of the study is to examine the different approaches to the recognition, measurement, and disclosure of goodwill, we accounted for this real business combination using the IFRS, PAR, CAR, and SAR accounting standards, with goodwill as the focus of the analysis.

Entities A and B, the subjects of the study, are both limited liability companies owned by Polish individual investors, with some equity relationship between them. Both companies do business in the same market and the business combination was seen as a way to increase economic potential through synergy. The business combination was booked in company A's ledger as it was the acquirer, and all intra-company receivables and liabilities were eliminated. Because the case is based on real financial data derived from Polish entities, all information required to perform the additional calculations to prepare the statement of financial position based on IFRS, CAR, and SAR were available to us with the restriction that the names of the entity and branch would be kept confidential.

First, all data were collected that were required to follow IFRS, PAR, CAR, and SAR accounting procedures for a business combination involving an acquisition. We further evaluated the legal process of the business combination with special consideration of the acquisition date and settlement, including the remuneration transferred as a result of the legal acquisition. Tab. I presents the details of the legal procedure of the business combination.

As a result of the acquisition, the share capital of company A increased to EUR 30.5 million. Although the nominal value of the capital increase was EUR 8 million, the market value of the shares issued on the day of the acquisition was estimated at more than EUR 27 million. The market value of the acquired company was based on the valuation of an independent expert, using the asset valuation methodology as of the date the common draft terms of the planned business combination were prepared. The significant difference between the book value of net assets and market value of company B is due to:

- the large amount of retained earnings disclosed in the equity of company $B$, and

- the reputation of company B based on its long history of building customer relationships and trademarks in the industry sector.

In the next step of our study, we carefully examined the data derived from the financial reports of companies A and B and recalculated each line of the statement of financial position into EUR, as the original currency was the Polish zloty. Tab. II shows that the acquiring company's (company A) total amount of assets is slightly higher than the amount of total assets of the acquired company (company B).

Among the book values of company $\mathrm{B}$, there is a deferred charge of EUR 426,822, which represents expenses incurred as part of the purchase process, such as legal and economic advisors, court fees, etc. This amount was not expensed when it was incurred but was booked in a separate account among short-term prepayments and deferred costs. Moreover, there are differences between the current values and fair values of company B's assets. As company B disclosed current liabilities on the day of acquisition, there were no differences between the book and fair values of the liabilities. In addition, based on business transactions conducted prior to the acquisition, intra-company receivables and liabilities, together with a loan of EUR 31 million, were presented in the statement of financial position. As a result of the analytical

I: Initial financial data presented in the common draft terms of the planned business combination (EUR)

\begin{tabular}{lrr}
\hline & Company A & Company B \\
\hline Nominal value of shareholders' capital & $22,500,000$ & $8,000,000$ \\
Net assets = equity & $50,077,107$ & $232,168,751$ \\
Increase in shareholders' capital as a result of the acquisition & $8,000,000$ & \\
\hline
\end{tabular}

Source: Authors' research 
II: Initial accounting data of combining entities (EUR)

\begin{tabular}{|c|c|c|c|}
\hline \multirow{2}{*}{ Item } & Company A & Company B & Company B \\
\hline & Book values & Book values & Fair values \\
\hline Long-term assets & $250,447,753$ & $165,387,817$ & $168,189,862$ \\
\hline Intangible fixed assets & 249,467 & $4,481,561$ & 10,205 \\
\hline Tangible fixed assets & $250,198,286$ & $8,916,418$ & $16,189,820$ \\
\hline Long-term investments & 0 & $151,989,837$ & $151,989,837$ \\
\hline Current assets & $107,087,620$ & $91,551,845$ & $83,449,696$ \\
\hline Inventories & $35,022,215$ & $31,236,050$ & $28,434,046$ \\
\hline Short-term receivables & $46,012,738$ & $54,042,069$ & $49,042,069$ \\
\hline Short-term investments & $26,052,667$ & $5,846,903$ & $5,546,758$ \\
\hline Deferred costs & 0 & 426,822 & 426,822 \\
\hline TOTAL ASSETS & $357,535,373$ & $256,939,662$ & $251,639,558$ \\
\hline Equity & $50,077,107$ & $232,168,751$ & 0 \\
\hline Share capital & $22,500,000$ & $8,000,000$ & 0 \\
\hline Retained earnings & $12,163,951$ & $221,769,096$ & 0 \\
\hline Profit/loss for the period & $15,413,156$ & $2,399,654$ & 0 \\
\hline Liabilities & $307,458,266$ & $24,770,911$ & $24,770,911$ \\
\hline Provisions & 0 & 0 & 0 \\
\hline Long-term liabilities & $215,048,737$ & 0 & 0 \\
\hline Short-term liabilities & $91,499,092$ & $24,770,911$ & $24,770,911$ \\
\hline Deferred income & 910,437 & 0 & 0 \\
\hline TOTAL EQUITY AND LIABILITIES & $357,535,373$ & $256,939,662$ & $24,770,911$ \\
\hline
\end{tabular}

Source: Authors' research

procedures conducted in the study, intra-company receivables and liabilities were eliminated.

Next, we applied the methodology adopted by each of the four legal accounting standards (IFRS, PAR, CAR, SAR), generating four statements of financial position for the same acquisition transaction. Transformation of pre-acquisition data into company A's post-acquisition statement of financial position was mainly focused on thorough application of IFRS and the three chosen methods for acquisition accounting with respect to coherent and comprehensive use of the available financial data.

Finally, we analysed the results using interpretive methods that allow recognizing the connection between the research focus and the phenomena in the disclosure of goodwill (negative goodwill) presented in the post-acquisition financial reports. In this part of the study we also applied the theoretical perspectives of goodwill accounting relating to relevant and faithful representation of the financial results of the acquisition transaction.

The main advantage of this methodology is not to examine the final statements of financial position but to go through the accounting for goodwill procedure step by step. However, it does not allow for expanded conclusion statements as the subject data were from the Central European countries of Poland, the Czech Republic, and Slovakia. The findings need to be considered in the context of emerging countries and non-publicly traded companies.

\section{RESULTS}

This section presents the results of our research, highlighting the contrasting approaches to the measurement of goodwill as well as its disclosure in the statement of financial position. Accounting for the business combination based on the four sets of regulations resulted in five different statements of financial position, because the Czech national regulations allow for two possible methods of calculating the acquisition difference. These statements are presented in Tab. III.

The results in Tab. III are consistent with our hypothesis that discrepancies between IFRS and domestic standards exist in the recognition, measurement, and disclosure of goodwill, as well as among the three neighbouring countries. Differences go beyond the disclosure of intangible assets, which include goodwill. This is mainly 
III: Statements of financial position as of the acquisition day (EUR)

\begin{tabular}{lrrrrr}
\hline \multicolumn{1}{c}{ Item } & \multicolumn{1}{c}{ IFRS } & \multicolumn{1}{c}{ PAR } & \multicolumn{1}{c}{ CAR 1 } & \multicolumn{1}{c}{ CAR 2 } & SAR \\
\hline Long-term assets & $254,599,253$ & $270,799,278$ & $62,579,342$ & $70,681,492$ & $70,681,492$ \\
\hline Intangible fixed assets & 249,467 & 259,672 & $4,731,029$ & $-199,858,115$ & $-199,858,115$ \\
\hline Tangible fixed assets & $250,198,286$ & $266,388,106$ & $53,696,814$ & $266,388,106$ & $266,388,106$ \\
\hline Long-term investments & $4,151,500$ & $4,151,500$ & $4,151,500$ & $4,151,500$ & $4,151,500$ \\
\hline Current assets & $158,619,423$ & $158,619,423$ & $166,721,573$ & $158,619,423$ & $158,619,423$ \\
\hline Inventories & $63,456,261$ & $63,456,261$ & $66,258,266$ & $63,456,261$ & $63,456,261$ \\
Short-term receivables & $63,563,736$ & $63,563,736$ & $68,563,736$ & $63,563,736$ & $63,563,736$ \\
\hline Short-term investments & $31,599,426$ & $31,599,426$ & $31,899,571$ & $31,599,426$ & $31,599,426$ \\
\hline Deferred costs & 0 & 0 & 0 & 0 & 0 \\
\hline TOTAL ASSETS & $413,218,676$ & $429,418,701$ & $229,300,915$ & $229,300,915$ & $229,300,915$ \\
\hline Equity & $235,068,906$ & $260,068,906$ & $76,151,145$ & $76,151,145$ & $76,151,145$ \\
\hline Share capital & $30,500,000$ & $30,500,000$ & $30,500,000$ & $30,500,000$ & $30,500,000$ \\
Retained earnings & $14,474,991$ & $14,901,813$ & $28,265,157$ & $28,265,157$ & $28,265,157$ \\
\hline Profit/loss for the period & $190,093,915$ & $214,667,093$ & $17,385,989$ & $17,385,989$ & $17,385,989$ \\
\hline Liabilities & $178,149,769$ & $169,349,794$ & $153,149,770$ & $153,149,770$ & $153,149,770$ \\
\hline Provisions & $25,000,000$ & 0 & 0 & 0 & 0 \\
Long-term liabilities & $67,460,400$ & $67,460,400$ & $67,460,400$ & $67,460,400$ & $67,460,400$ \\
Short-term liabilities & $84,778,932$ & $84,778,932$ & $84,778,933$ & $84,778,933$ & $84,778,933$ \\
\hline Deferred income & 910,437 & $17,110,462$ & 910,437 & 910,437 & 910,437 \\
\hline TOTAL EQUITY AND LIABILITIES & $413,218,676$ & $429,418,701$ & $229,300,915$ & $229,300,915$ & $229,300,915$ \\
\hline Soure: Aut & & & & & \\
\hline
\end{tabular}

Source: Authors' research

because this business combination resulted in negative goodwill. The consideration transferred to the owners of company B, in the form of shares, was valued at EUR 27 million (nominal value EUR 8 million) and did not exceed the fair value of net assets acquired by company A. Moreover, the purchase price, mainly based on the amount of consideration transferred, was calculated differently in all five cases (see Tab. IV). Note that since Czech national regulations allow the acquirer to account for the acquired assets and liabilities either at their book values (CAR 1-recognition of 'Valuation difference to acquired assets') or account for the assets acquired at their fair values (CAR 2recognition of 'Goodwill'), there are two possible presentations of the transaction in the acquirer's balance sheet. It is the acquirer's choice whether to account for the acquired assets and liabilities at their book value (as reported in the acquired company's balance sheet) or to have the assets revalued to their fair values by an independent expert, and account for them at their fair values. Even though the presentation of the transaction according to Slovak national regulations resulted in the same presentation in the acquirer's balance sheet as in the case of CAR 2, there is one significant difference in the goodwill calculation. Unlike the Czech national regulations, Slovak national regulations require both acquired assets and acquired liabilities to be accounted for at their fair value in the acquirer's balance sheet. Since the fair value of Company B's liabilities in the transaction analysed equals their book value, there is no obvious difference between the CAR 2 solution and the SAR solution, as the difference in these two approaches is hidden in the valuation of liabilities and the goodwill calculation.

All financial data presented in Tab. IV refer to the accounting equation that must be maintained to account for a business combination. As the purchase method was used to account for the business combination of companies $\mathrm{A}$ and $\mathrm{B}$, the main issue concerns the difference between the market value of consideration transferred and the fair value of the net assets acquired by company A. In each case, there is a difference, as the purchase price is less than the net assets purchased. As seen in Tab. IV, the different accounting standards result in very dissimilar presentations of the difference. According to IFRS, the difference affects profit (loss) for the period, while in the financial reports based on Polish regulations, it is presented among liabilities as deferred income. Conversely, the difference is presented in Czech and Slovak financial reports among either tangible or intangible assets. The way 
IV: The excess of the purchase price over fair value of net assets acquired (EUR)

\begin{tabular}{|c|c|c|c|c|c|}
\hline Item & IFRS & PAR & CAR 1 & CAR 2 & SAR \\
\hline $\begin{array}{l}\text { Nominal value of issued shares = increase } \\
\text { in shareholders' capital }\end{array}$ & & & $8,000,000$ & & \\
\hline Market value of shares issued & & & $27,000,860$ & & \\
\hline $\begin{array}{l}\text { Additional expenses (referring to } \\
\text { the business combination procedure) } \\
\text { increasing the purchase price }\end{array}$ & $\begin{array}{c}\text { Expensed } \\
\text { on the day } \\
\text { of occurrence } \\
\end{array}$ & 426,822 & $\begin{array}{l}\text { Expensed } \\
\text { on the day } \\
\text { of occurrence }\end{array}$ & $\begin{array}{l}\text { Expensed } \\
\text { on the day } \\
\text { of occurrence } \\
\end{array}$ & $\begin{array}{c}\text { Expensed } \\
\text { on the day } \\
\text { of occurrence } \\
\end{array}$ \\
\hline Total purchase price & $27,000,860$ & $27,427,682$ & $27,000,860$ & $27,000,860$ & $27,000,860$ \\
\hline Fair value of assets acquired & $251,639,558$ & $251,639,558$ & N/A & $251,639,558$ & $251,639,558$ \\
\hline Fair value of liabilities acquired & $24,770,911$ & $24,770,911$ & $\mathrm{~N} / \mathrm{A}$ & $24,770,911$ & $24,770,911$ \\
\hline Fair value of net assets purchased & $226,868,646$ & $226,868,646$ & $\mathrm{~N} / \mathrm{A}$ & $226,868,646$ & $226,868,646$ \\
\hline Book value of assets acquired & N/A & $\mathrm{N} / \mathrm{A}$ & $256,939,662$ & $\mathrm{~N} / \mathrm{A}$ & N/A \\
\hline Book value of liabilities acquired & N/A & N/A & $24,770,911$ & N/A & $\mathrm{N} / \mathrm{A}$ \\
\hline Book value of net assets purchased & N/A & $\mathrm{N} / \mathrm{A}$ & $232,168,751$ & $\mathrm{~N} / \mathrm{A}$ & $\mathrm{N} / \mathrm{A}$ \\
\hline $\begin{array}{l}\text { Difference (purchase price - net assets } \\
\text { acquired) }\end{array}$ & $200,117,786$ & $199,690,964$ & $-205,417,891$ & $-200,117,786$ & $-200,117,786$ \\
\hline The wording used to describe the difference & $\begin{array}{l}\text { Bargain } \\
\text { purchase }\end{array}$ & $\begin{array}{l}\text { Negative } \\
\text { goodwill }\end{array}$ & $\begin{array}{c}\text { Valuation } \\
\text { difference of } \\
\text { acquired assets } \\
\end{array}$ & Goodwill & Goodwill \\
\hline Final amount disclosed in financial report & $158,667,761$ & $16,200,025$ & $-205,417,891$ & $-200,117,786$ & $-200,117,786$ \\
\hline Position of disclosure & $\begin{array}{l}\text { Profit for } \\
\text { the period } \\
\text { (equity) }\end{array}$ & $\begin{array}{l}\text { Deferred } \\
\text { income } \\
\text { (liabilities) }\end{array}$ & Tangible asset & $\begin{array}{l}\text { Intangible } \\
\text { asset }\end{array}$ & $\begin{array}{l}\text { Intangible } \\
\text { asset }\end{array}$ \\
\hline
\end{tabular}

Source: Authors’ research

the discrepancy is disclosed in the financial reports is the main reason for the completely different structures of the statement of financial position and the amount of profit for the period (see Tab. III and Fig. 1).

The amount of total assets calculated in accordance with IFRS and PAR is almost double that of CAR and SAR (187\%). Long-term assets per PAR are 4.3 times greater than those disclosed under CAR, while the difference in current assets amounts to 5\% (see Fig. 1). A deeper analysis of long-term assets reveals an enormous disparity in the values of tangible and intangible assets. When we compare the amounts of tangible assets disclosed in each scenario, we find that the amount of tangible assets disclosed in CAR 1 differs significantly from the other scenarios. The value of tangible assets disclosed under CAR 1 is approximately five times less than value of tangible assets disclosed in the other scenarios. The reason is that the acquisition difference in CAR 1 (i.e. valuation difference of acquired assets) is reported in the balance sheet as a negative tangible asset. Moreover, the methodology that guides CAR 1 financial reports does not allow

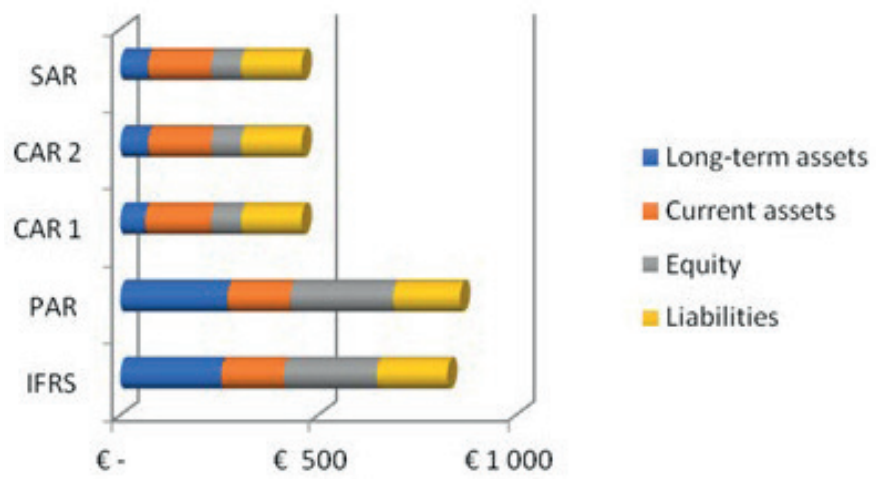

1: Structure of the statement of financial position as of the day of acquisition (mln EUR)

Source: Authors' research 
revaluation of the assets and liabilities acquired, which is why the value of intangible assets reported in this scenario is the highest. In this transaction, the value of the intangible assets of the acquired company (Company B) were decreased significantly as a result of the transaction revaluation process. This decrease in value is ignored by the method employed in the CAR 1 scenario. SAR and CAR 2 scenarios yield identical results as far as the balance sheet of the acquirer (Company A) is concerned. Still, there is an important difference in the methodology used in these two scenarios regarding valuation of liabilities (see above). Both SAR and CAR 2 lead to a negative value of intangible assets. This is due to the rather low fair value of intangible assets acquired and even more so to the great difference between the value of net assets acquired and the value of the business as a whole based on the valuation done by the independent expert. This discrepancy resulted in rather high negative goodwill value that is (under SAR and CAR 2) reported as an intangible asset.

Although share capital is the same in each financial report, the maximum difference in the value of equity approximates 342\%. The difference is comprised of retained earnings (189\%) and profit for the period (1 235\%). The greatest difference among the five financial reports is profit for the period, due to the way additional expenses (incurred during the business combination legal procedure) were booked and because of the approach to the bargain purchase. The variation between the maximum and minimum values of liabilities disclosed total EUR 25 million, which consists of provisions disclosed only in the IFRS financial report. Provisions were booked in the process of revaluing the assets and liabilities acquired by company A to their fair values. In the first step of the re-measurement process due to a bargain purchase, intangible and tangible asset values were decreased to zero. The second step consisted of disclosure of the provisions for future anticipated costs. As a result, the bargain purchase of EUR 159 million increased the reported profit for the period.

\section{DISCUSSION}

Given our literature and regulatory reviews, we assumed that financial reports would be diversified in terms of goodwill presentation. Notably, the methods for recognition, measurement, and disclosure of goodwill in the three Central European countries have significant differences that can be observed in financial reports. In this context, our findings are in accordance with previous literature calling for worldwide accounting harmonization. That is, we identified that accounting practices do not always follow the fundamentals of accounting. In theory, as an economic resource, goodwill may be defined as the excess of the value of a business as a whole over the values of its individual tangible and intangible net assets. In practice, in two out of the three selected countries we found that goodwill serves only as a balancing item.

The discrepancies identified are both conceptual and methodological. The differences arise mainly because of opposing consolidation concepts that were used as the basis for IFRS, PAR, CAR, and SAR statements. International standards are based on the theory of the economic entity, while PAR solutions were built upon parent company extension theory. On the other hand, CAR and SAR constitute a peculiar hybrid of contrasting theories. Furthermore, the dissimilarities of accounting for goodwill originate because of the contrasting measurement bases, as SAR does not allow for fair value measurement of net assets acquired. This contradiction results in huge discrepancies in the amount of goodwill as well as in the value of total assets. In addition to the different measurements for goodwill, there are also contrasting subsequent accounting standards for the following years. IFRS do not allow for amortization of goodwill and impairment tests are required, encompassing cash generating unit recognition. On the other hand, PAR, CAR, and SAR allow for straight-line amortization of goodwill, creating another significant difference in the presentation of the economic phenomena of a business combination.

Another important disparity observed relates to negative goodwill or gain from a bargain purchase.

V: Accounting for goodwill-similarities and differences

\begin{tabular}{|c|c|c|c|c|}
\hline Issue & IFRS & PAR & CAR & SAR \\
\hline Goodwill as a separate item in the statement of financial position & Yes & Yes & Yes & Yes \\
\hline Goodwill is subject to impairment only & Yes & Yes & No & No \\
\hline $\begin{array}{l}\text { The existence of a relationship between the amount of goodwill and non-controlling } \\
\text { interests measurement }\end{array}$ & Yes & No & Yes & No \\
\hline
\end{tabular}

Source: Authors' research 
In the case of IFRS financial reporting, the excess of the fair value of net assets over the purchase price is presented among profits for the period, while PAR calls for a separate liability item called negative goodwill and partial disclosure as profit for the period. Under CAR and SAR, the excess is disclosed among assets as a negative value. The major differences among IFRS, PAR, CAR, and SAR accounting for positive and negative goodwill are described in Tab. V

We found that these differences among the existing accounting regulations in three Central European countries are the source of the fundamental differences among financial reports. This raises a question about the faithful representation of the economic phenomena of business combinations and possible usage of these dissimilarities for earnings management practices in the case of acquisition transactions. The distinct differences identified also raise a question about whether users of financial reports can compare the economic information about the value of business combinations and their financial consequences. Each entity discloses a different value of total assets, a contrasting structure of assets and liabilities, and dissimilar profit for the period.

Overall, we find that the recognition, measurement, and disclosure of goodwill does not convey relevant information for investors of companies from Poland, the Czech Republic, and Slovakia. In financial reports prepared in accordance with Czech or Slovak accounting rules, goodwill is seen as an arithmetic exercise and thus does not provide information about the future acquirer's performance. Moreover, there is no link between the theoretical underpinnings of goodwill described in prior literature or in the development of IFRS for business combinations and the methodology used in Czech or Slovak accounting for business combinations. In other words, present accounting for goodwill does not follow international guidance that describes this economic resource as a special result of a business combination transaction. A negative value of intangibles (observed in Czech and Slovak financial reports) questions the faithful representation of assets as future economic benefits resulting from past events. On the other hand, disclosure of goodwill according to PAR is much closer to IFRS solutions, although Polish standards are based on different theoretical underpinnings. Polish regulations were established when the previous international standard (IAS 22) was in force. Therefore, although the Polish solution does not treat goodwill only as a balancing item, the law is based on a theoretical basis derived from an international background. However, PAR has not kept up with the changes introduced to IFRS in 2001.

The results show a lack of consistent rules in the accounting regulations of Poland, the Czech Republic, and Slovakia in terms of positive and negative goodwill and supports our hypothesis. Moreover, it stresses that present accounting regulations distort the economic content of the statement of financial position, leading to questions about the faithfulness of the financial reporting presentation of economic phenomena in the context of goodwill. We showed in this case study that comparing financial reports is impossible and the decision usefulness of the disclosures is adversely affected.

\section{CONCLUSION}

Using a case study of a business combination of two Polish entities, we investigated the scope of differences in IFRS, PAR, CAR, and SAR goodwill accounting. Our research design allows us to compare four sets of standards, thus omitting company specific variables. The results of the study show large discrepancies in the recognition, measurement, and disclosure of goodwill (negative goodwill) arising from a business combination. The differences among IFRS, PAR, CAR, and SAR can be observed both in the amount and structure of assets and liabilities. Second, we found that discrepancies also occur in the statement of profit and loss. Contrasting financial results were disclosed in the financial reports as a consequence of the business combination, constituting the second biggest discrepancy resulting from non-convergence of accounting for business combinations.

As goodwill is a kind of 'financial outcome' of a company acquisition transaction, dissimilarities occur in the characteristics and value of this item presented in the statement of financial position. Based on the study, four different reporting consequences can be observed:

- negative goodwill displayed as a positive number in the liabilities group,

- goodwill reported as a negative number within intangible assets,

- a valuation difference presented as a negative number among tangible assets, and

- profit for the period instead of goodwill in the statement of financial position.

Moreover, due to contemporary dualism of accounting regulations in Poland, the Czech Republic, and Slovakia (IFRS vs. domestic accounting regulations), the possible disclosures of business combinations are not limited to the solutions presented in this study. In each country, there is a possibility that a business combination will be accounted for in accordance with IFRS, particularly in the case of publicly traded entities. 
The situation described makes comparability of financial situations almost impossible, especially in the case of accounting for cross-border acquisitions of neighbouring Polish, Czech, and Slovak entities. In light of the regulations enforced by the European directive on cross-border mergers, contradictions within the accounting regulations do not encourage free movement of capital among these countries. Based on this study, we point out the need for changes within domestic laws referring to accounting for business combinations. Maintaining the current status of domestic accounting regulations constitutes a major obstacle for investors, increasing inter alia transaction costs. We assert that standardization of accounting for acquisitions is a must among the three neighbouring countries, preferably based on IFRS. These conclusions are in the line with previous research stating that convergence of accounting practices helps reduce discrepancies and limits earnings management practices that lower the quality of financial reporting.

Considering usefulness of the information presented in financial statements as its primary characteristic (conceptual framework), we point to distortions in the case of goodwill accounting. The various effects of the same transaction presented in the financial statements using accounting standards from Poland, the Czech Republic, Slovakia, and IFRS show that, from an investor's point of view, information regarding goodwill cannot be considered useful for decision-making, and may lead to different investor decisions in each case.

Finally, the study confirms that the accounting treatment of goodwill still constitutes a source of debate and opinion. This result is not surprising, given the sophisticated economic nature of this economic resource. Consistent with this, we see that there is a long way to go to clarify the nature of goodwill and improve how it is accounted for, as well as providing a relevant and faithful representation of goodwill in financial reports. On the other hand, we acknowledge that the results of our study may not be generalizable to other countries. However, we believe that our results may be generalizable to other emerging market countries with similar economic and political environments, namely to other Central Eastern countries. Thus, our results reveal the need for harmonization of accounting for goodwill, preferably in accordance with IFRS.

As this is a descriptive study, the focus was on drawing a general picture of goodwill recognition, measurement, and disclosure practices in Central European countries. Future research is recommended to deepen the study and investigate the consequences of the discrepancies identified in cross-border business combinations.

Acknowledgements

This work was supported by the University of Economics Prague under Grant "Relevance of accounting information on the consolidated basis in business and public sector” number 47/2015.

\section{REFERENCES}

ABUGHAZALEH, N. M., AL-HARES, O. M. and ROBERTS, C. 2011. Accounting Discretion in Goodwill Impairements: UK Evidence. Journal of International Financial Management \& Accounting, 22(3): 165-204.

BEATTY A. and WEBER, J. 2006. Accounting Discretion in Fair Value Estimates: An Examination of SFAS 142 Goodwill Impairments. Journal of Accounting Research, 44(2): 257-288.

BINI, M. and BELLA, C. D. 2007. Determinants of Market reactions to Goodwill Write-off after SFAS 142. Managerial Finance, 33(1): 904-914.

BUGEJA, M. and GALLERY, N. 2006. Is Older Goodwill Value Relevant? Accounting \& Finance, 46(4): 519-535.

CARVAlHO, C., RODRIGUES, A. M. and FERREIRA, C. 2016. The Recognition of Goodwill and Other Intangible Assets in Business Combinations - The Portuguese Case. Australian Accounting Review, 76(26): 4-20.

CHAMBERS, D. and FINGER, C. 2011. Goodwill Non-Impairments. The CPA Journal, 81(2): 38-41.

COPELAND, R. M. and WOJDAK, J. F. 1969. Income manipulation and the purchase-pooling choice. Journal of Accounting Research, 7(2): 188-195.

CHALMERS, K. G., GODFREY, J. M. and WEBSTER, J. C. 2011. Does a goodwill impairment regime better reflect the underlying economic attributes of goodwill? Accounting and Finance, 51(3): 634660.

CHURYK, N. T. 2005. Reporting goodwill: are the new accounting standards consistent with market valuations? Journal of Business Research, 58(10): 1353-1361.

COMISKEY, E. E., CLARKE J. E. and MULFORD, C. W. 2010. Is Negative Goodwill Valued by Investors? Accounting Horizons, 24(3): 333-353. 
CZECH REPUBLIC. 2002. Vyhláška č. 500 k provedení zákona o účetnictví. In: Sbírka zákonů České republiky. Edition: 174, pp. 9690-9768

DEMOVILLE, W. and PETRIE, G. 1989. Accounting for bargain purchase in a business combination. Accounting Horizons, 2(September): 38-43.

DEANGELO, L. E. 1990. Equity valuation and corporate control. Accounting Review, 65(1): 93-112.

FINANCIAL ACCOUNTING STANDARDS BOARD OF THE FINANCIAL ACCOUNTING FOUNDATION. 2009. Business Combinations. SFAS 141. FAF.

FINANCIAL ACCOUNTING STANDARDS BOARD OF THE FINANCIAL ACCOUNTING FOUNDATION. 2001. Goodwill and Other Intangible Assets. SFAS 142. FAF.

FRANCIS, J. R. and MARTIN, X. 2010. Acquisition profitability and timely loss recognition. Journal of Accounting and Economics, 49(1-2): 161-178.

GAUM, M. and WYRWA, S. 2011. Making Acquisition Transparent: Goodwill Accounting in Times of Crisis. Price Waterhouse Coopers and AG WPG.

HENDRIKSEN, E. A. 1970. Accounting Theory, Richard D. Irvin, Inc., Homewood, [quoted in] Miller, M. C., 1973. Goodwill - An Aggregation Issue. Accounting Review, 48(2): 280-291.

HENNING, S. L., LEWIS, B. L. and SHAW, W. H. 2000. Valuation of the Components of Purchased Goodwill. Journal of Accounting Research, 38(2): 375-386.

HUGHES, H. P. 1982. Goodwill in Accounting: A History of the Issues and Problems. Working Paper. Georgia State University.

INTERNATIONAL ACCOUNTING STANDARDS BOARD. 1983. Business Combinations. IAS 22.

INTERNATIONAL ACCOUNTING STANDARDS BOARD. 2008. Business Combinations. IFRS 3. [Online]. Available at: http://www.ifrs.org/issued-standards/list-of-standards/ifrs-3-business-combinations/ [Accessed: 2018, October 10].

JENNINGS, R. J., ROBINSON, J., THOMPSON, R. B. and DUVALL, L. 1996. The Relation between Accounting Goodwill Numbers and Equity Values. Journal of Business Finance \& Accounting, 23(4): 513-533.

JOHNSON, J. and TEARNEY, M. G. 1993. Goodwill: An Eternal Controversy. CPA Journal, 63(4): 58-62. KAMELA-SOWIŃSKA, A. 1996. Wartość firmy. Warsaw: PWE.

KIMBRO, M. B. and XU, D. 2016. The accounting Treatment of Goodwill, Idiosyncratic Risk, and Market Pricing. Journal of Accounting, Auditing \& Finance, 31(3): 365-387.

LYCKLAMA À NIJEHOLT, M. P., GRIFT, Y. K. and BLOMMAERT, J. M. J. 2012. Goodwill measuring value creation of acquisitions: an empirical research. Working Paper. Tjalling C. Koopmans Research Institute.

LYCKLAMA M. P. 2010. Goodwill and value creation of acquisition. Ph.D. Thesis. Leiden University, Meljers Institute for Legal Studies.

MCCARTHY, M. G. and SCHNEIDER, D. G. 1995. Market Perception of Goodwill: Some Empirical Evidence. Accounting and Business Research, 26(1): 45-64.

MARUSZEWSKA, E. W. and STROJEK-FILUS, M. 2016. Ambiguity of goodwill regulations - a case of polish publicly traded enterprises. ACRN Oxford Journal of Finance and Risk Perspectives, 5(1): 5270.

MCNICHOLS, M. F. and STUBBEN, S. R. 2015. The effect of target-firm accounting quality on valuation in acquisitions. Review of Accounting Studies, 20(1): 110-140.

MILLER, M. C. 1973. Goodwill - An Aggregation Issue. Accounting Review, 48(2): 280-291.

POSPÍŠIL, J. and STROJEK-FILUS, M. 2017. Comparison of Accounting for Mergers in the Czech Republic and Poland. In: New Trends in Finance and Accounting - Proceedings of the $17^{\text {th }}$ Annual Conference on Finance and Accounting Prague. Praha, 27 $7^{\text {th }}$ May. Switzerland: Springer International Publishing, pp. 419-431.

POSPÍŠIL, J. and VOMÁČKOVÁ, H. 2017. Net Assets Valuation in Transformations of Czech Companies. Journal of Applied Economic Sciences, 12(7): 1906-1917.

POSPÍŠIL, J. and VOMÁČKOVÁ, H. 2018. Business Combinations of Czech Companies: Empirical Analysis of Their Typology. Acta Universitatis Agriculturae et Silviculturae Mendelianae Brunensis, 66(1): 313-323.

RAMANNA, K. 2008. The Implications of Unverifiable Fair-value Accounting: Evidence from the Political Economy of Goodwill Accounting. Journal of Accounting and Economics, 45(2-3): 253-281.

RAMANNA, K. and WATTS, R. 2008. Evidence from Goodwill Non-Impairments on the Effects of Unverifiable Fair-value accounting. Working Paper. Harvard Business School.

RAYBURN, F. R. and POWERS, O. S. 1991. A history of pooling of interests accounting for business combinations in the United States. Accounting Historians Journal, 18(2): 155-192.

SHALEV, R., ZHANG, I. and ZHANG, Y. 2013. CEO Compensation and fair Value accounting: Evidence From Purchase Price allocation. Journal of Accounting Research, 51(4): 820-852. 
SLOVAK REPUBLIC. 2002. Zákon č. 431 o účtovníctve. In: Zbierka zákonov Slovenské republiky. Edition: 168. Pp. 4455-4469.

STROJEK-FILUS, M. 2013. Determinanty oraz skutki wynikowo-bilansowe identyfikacji i rozliczania wartości firmy $w$ grupie kapitałowej. Katowice: Wydawnictwo Uniwersytetu Ekonomicznego w Katowicach.

STROJEK-FILUS, M. and MARUSZEWSKA, E. W. 2016. New intangible assets derived from goodwill - globalization of Polish entities' accounting practice. In: Globalization And Its Socio-Economic Consequences - Proceedings of $16^{\text {th }}$ International Scientific Conference. Zilina: University of Zilina, pp. 2151-2158.

UHLENBRUCK, K. and DE CASTRO, J. O. 2000. Foreign acquisitions in Central and Eastern Europe: Outcomes of privatization in transitional economics. Academy of Management Journal, 43(3): 381402.

VAN HULZEN, P., ALFONSO, L., GEORGAKOPOULOS, G. and SOTIROPOULOS, I. 2011. Amortization Versus Impairment of Goodwill and Accounting Quality. International Journal of Economic Sciencies and Applied Research, 4(3): 93-118.

VERRIEST, A. and GAEREMYNCK, A. 2009. What Determines Goodwill Impairment? Review of Business and Economics, 54(2): 1-23.

ZANG, Y. 2008. Discretionary behaviour with respect to the adoption of SFA no. 142 and the behavior of security prices. Review of Accounting \& Finance, 7(1): 38-68. 